\title{
NILAI-NILAI PENDIDIKAN ISLAM YANG TERKANDUNG DALAM IBADAH SHALAT BERJAMA'AH SANTRI USIA REMAJA DI YAYASAN AL-HIKMAH MUSTHOPA PLERED - PURWAKARTA
}

\section{Saiful Bahri, Hayaturrohman, Mustaqim}

Prodi Pendidikan Agama Islam, Fakultas Agama Islam, Universitas Nahdlatul Ulama Indonesia

E-mail: saifulbahri@unusia.ac.id

\begin{abstract}
Article Information
Informasi Artikel

Naskah diterima:

February 2019

Naskah direvisi: 15

Maret 2019

Naskah disetujui: 30

Maret 2019

Naskah dipublish: 10

April 2019

Keywords Pendidikan

Islam, Sholat

Berjamaah, Yayasan AlHikmah

\section{Abstract}

Dalam shalat berjama'ah banyak nilai-nilai pendidikan

27 Islam yang berorientasi terhadap kesuksesan seseorang dalam berikhtiar untuk kehidupan duniawinya. Penelitian ini bertujuan untuk mengetahui pelaksanaan praktek shalat berjama'ah dan nilai-nilai pendidikan Islam yang terkandung dalam ibadah shalat berjama'ah santri usia remaja di Yayasan Al-Hikmah Mustofa Plered Purwakarta. Jenis penelitian ini deskripstif kualitatif. Dengan teknik pengumpulan berupa teknik observasi, wawancara dan dokumentasi. Hasil penelitian di Yayasan Al-Hikmah Mustofa Plered Purwakarta shalat berjama'ah dapat membentuk santri yang berakhlak, baik Akhlak terhadap Allah, akhlak terhadap manusia, maupun akhlak terhadap alam/lingkungan. Adapun faktor pendukung dalam pelaksanaan shalat berjama'ah diantaranya adanya dukungan yang baik dari orangtua, keteladanan yang baik dari guru, dan sikap semangat dari santri serta tanbih yang di tetapkan oleh Yayasan. Sedangkan faktor penghambatnya adalah lemahnya kesadaran santri akan manfaat dari melaksanakan shalat berjama'ah.
\end{abstract}

\section{PENDAHULUAN}

Sebagai agama multidimensi, islam tidak hanya mengajarkan konsepsi spiritual (ibadah), melainkan juga konsepsi social (mu'amalah) dan moral (akhlak). Ajarannya mencakup semua sisi kehidupan, dunia akhirat. Prinsip keseimbangan (tawazun) dalam ajarannya, senantiasa dijaga agar umat tidak terjebak dalam keekstriman, baik ekstrim kiri maupun kanan.

Shalat pada dasarnya adalah ibadah murni (ibadah mahdhah). Namun, jika dikaitkan dengan jama'ah, jelas ibadah ini telah memasuki ruang sosial. Jama'ah mengumpulkan manusia, menyatukan mereka dalam satu barisan untuk berjalan 
menuju satu tujuan. Dalam sehari, berkumpul lima kali, dalam seminggu berkumpul sekali setiap jum'at, dan dalam setahun berkumpul dua kali dalam momentum idul fitri dan iduladha. Dengan intensitas pertemuan yang rutin semacamini, dapat dibayangkan betapa besar dan kokohnya potensi persatuan dikalangan umat Islam. Untuk itu perlu adanya penjelasan lagi bahwa Allah SWT tidak akan salah dan tidak perlu diragukan lagi dengan memerintah manusia supaya melaksanakn shalat lima waktu secara berjama'ah. Dengan kesungguhan shalat berjama'ah, maka hal tersebut akan jadi kebutuhan bagi manusia itu sendiri. Karena sesungguhnya untuk mencetak generasi Islam yang siap menghadapi tantangan dan godaan dunia global, tidak hanya melalui lembaga yang formal yang di dalam terdapat berbagai ilmu teknologi dan pengetahuan umum. Tetapi dalam shalat berjama'ah secara istiqomah manusia juga akan mendapatkan berbagai pendidikan khususnya pendidikan Islam. Pendidikan yang matang juga tidak hanya terletak pada canggihnya alat atau sarana pendidikan, tetapi kesanggupan manusia bermasyarakat dengan baik dan sukses merupakan anggapan masyarakat bahwa manusia tersebut adalah manusia yang berhasil dunia akhirat. Demi keberhasilan tersebut, manusia harus selalu berusaha dan berdo'a melalui shalat berjama'ah. Jangan sampai dunia ini rusak dan rapuh karena sudah tidak adanya orang yang melakukan shalat berjama'ah.

Yayasan Al-Hikmah Mustofa Plered Purwakarta memiliki keunikan dan perbedaan dengan yayasan lain yaitu, selalu mengamalkan manakib Tuan Syaik Abdul Qodir Al-Zailani pada awal bulan nya, sehingga banyak orang-orang yang berdatangan ataupun mereka mengundang kepada yayasan tersebut untuk di bacakan manakib di tempat mereka masing-masing. Di Yayasan ini santri tidak hany a diajarkan ilmu agama saja, melainkan dengan dibekali ilmu-ilmu pertanian, peternakan dan lain sebagainya sesuai karakter santri itu sendiri. Begitupun dengan shalat berjama'ah, di Yayasan ini Santri melaksanakan shalat berjama'ah kadang di yayasan tersebut dan kadang pula dengan masyarakat setempat yang ada di sana serta dilaksanakan di masjid agung setempat.

Aturan-aturan yang sudah ditetapkan, seiring usia remaja tiba kadang rasa kurang nyaman, ingin bertindak semaunya sendiri serta emosional yang tidak terkontrol, yang tadinya aktif melaksanakan kegiatan-kegiatan yang ada, perlahanlahan mulai pasif. Tapi keadaan yayasan dengan aturannya tidak dapat di ganggu gugat 
dengan mengedepankan ukhuwah islamiyah, basyariyah dan wathoniyah. Karena memang hidup tidak akan tetap, kadang bertambah kadang berkurang. Manakib saja dapat menimbulkan dan mewujudkan nilai-nilai pendidikan Islam dengan sangat selaras, apalagi dengan nilai-nilai pendidikan Islam yang terkandung dalam ibadah shalat berjama'ah, pastinya akan lebih menonjol keutamaan yang baik dalam segi apapun, ketika nilai-nilai pendidikan Islam itu dipahami dan dijalankan dengan rileks.

\section{METODOLOGI}

Metode penelitian yang digunakan yaitu penelitian kualitatif. Penelitian kualitatif adalah "prosedur yang menghasilkan data deskriptif berupa kata-kata tertulis atau lisan dari orang-orang dan perilaku yang diamati”. ${ }^{1}$ Berdasarkan pada jenis permasalahannya yang dibahas dalam penelitian ini, maka peneliti menggunakan penelitian deskriptif. Berdasarkan penelitian di atas, penelitian deskriptif merupakan penelitian yang berusaha memaparkan suatu gejala ataupun keadaan secara sistematis sehingga objek peneliti menjadi jelas. Dalam hal ini, penelitian deskriptif berkaitan dengan Nilai-nilai pendidikan Islam yang terkadung dalam ibadah shalat berjama'ah santri usia remaja di yayasan al-hikmah mustofa plered purwakarta.

Peneliti mendapatkan hasil penelitian dari pengurus yayasan, pendidik dan qlangsung kepada santri usia remaja di Yayasan Al-Hikmah Mustofa Plered Purwakarta. Untuk mendapatkan data yang valid dan relevan pada penelitian ini, maka penulis melakukan metode pengumpulan data dengan cara sebagai berikut; a) Data primer dilakukan dengan wawancara para pengurus, para tenaga pendidik dan santri Yayasan Al Hikmah Mustopa Plered. b) Data Sekunder, sebagai sumber penunjang disini adalah berupa literatur-literatur yang membahas tentang nilai-nilai pendidikan islam yang terkandung dalam ibadah shalat berjama'ah.

\section{SEKILAS YAYASAN AL-HIKMAH MUSTOPA PELERED PURWAKARTA}

Yayasan Al-Hikmah Mustopa secara geografis termasuk dalam wilayah Empangsari, Desa Plered, Kecamatan Plered, Kabupaten Purwakarta Provinsi Jawa Barat. Untuk lebih jelasnya alamat Yayasan Al-Hikmah Mustopa yaitu ada di Kampung Empangsari. Jalan Warungkandang RT.12, RW.04 Segalanya bermula dari desa sukaweni - wanaraja - garut, tatkala seorang pemuda yang bernama Rd. Mustofa

\footnotetext{
${ }^{1}$ Sugiyono, Metode Penelitian Kuantitaif, Kualitatif, dan R\&D, (Bandung: Alfabeta,cv 2017), h.7
} 
memutuskan untuk hijrah menuju sebuah desa kecil di karisidenan purwakarta pada akhir abad ke 20, desa tempat ia melabuhkan seluruh kehidupannya hingga akhir hayatnya, plered 1928. Karena keluhuran pribadinya, Rd. Mustofa mendapat tempat dihati keluarga seorang ulama besar plered, KH. Rd. Abdus Somad yang membina pesantren salafiyah. Rd. Mustofa kemudian dinikahkan dengan putri sulungnya $\mathrm{KH}$. Rd. Abdus Somad yaitu Nyai. Hj. Siti Halimah. Ibu Nani Sa'adah adalah generasi ke tiga Rd. Mustof a yang tergerak untuk meretas jalan kedermawanan sang leluhur dengan mendirikan sebuah yayasan yang di beri nama Yayasan Al-Hikmah Mustofa.

Berdasarkan kegalauan dan keinginan yang kuat Pendiri Yayasan Al-Hikmah Mustopa dan didorong oleh seluruh pengurus Yayasan Al-Hikmah Mustopa maka pada tahun 1997, berdirilah Yayasan Al Hikmah Mustopa Plered Purwakarta di bawah kepemipinan Bapak Diki Muhtar, S.Ag. Sejak pertama didirikan sampai tahun 2015 Yayasan Al-Hikmah Mustopa telah meluluskan 250 santri terdiri dari lulusan SMP dan SMA, dan pada itu pula telah memiliki sawah seluas 1 hektar dan kolam ikan seluas $500 \mathrm{~m}$ persegi. Dan yang paling penting konsep pendidikan di Yayasan Al-Hikmah Mustofa yaitu dengan kemandirian dan kepercayaan, terlebih itu santri diajarkan dengan ilmu pertanian, perikanan dan lain sebagainya sesuai potensi dan skil masingmasing santri, untuk menunjang para santri di masa yang akan datang.

Adapun peringatan yang dikeluark an di Yayasan Al-Hikmah Mustofa adalah : 1. Santri wajib mentaati guru 2. Santri wajib mengikuti pengajian pada waktunya 3. Santri wajib mengikuti shalat berjama'ah 4 . Santri wajib mengikuti ziarah pada hari kamis sore 5. Santri dilarang keluar lewat jam 22.00 6. Santri keluar satu hari harus izin 7. Santri dilarang memutar music di area pesantren 8 . Santri yang tangan panjang harus di istirahatkan, (Barang siapa yang melanggar Undang-Undang diatas akan dikenakan sanksi/ta'jiran). Harapan ditahun ini Yayasan Al-Hikmah Mustofa ingin membangun tempat pendidikan formal sampai jenjang perguruan tinggi. Adapun yang paling berkesan dari harapan salah satu pengurus Yayasan adalah Tidak bergantung kepada apapun dan siapapun terkecuali kepada Allah SWT.

Salah satu sisi yang menjadi tanggung jawab Yayasan yaitu mempersiapkan santri agar mampu mengembangkan kepribadiannnya yang selaras, seimbang antara kedewasaan jasmaniyah dan rohaniyah. Sehingga anak dapat tumbuh dan berkembang sesuai dengan usianya atau yang diharapkan akan melahirkan sumber daya manusia 
yang berkualitas,sehat cerdas dan terampil serta menjadi anak-anak yang Soleh dan solehah. Untuk mewujudkan harapan tersebut maka Yayasan Al Hikmah Mustopaperlu mengadakan kegiatan yang sesuai dengan kemampuan anak didik dan kegiatan yang menunjang untuk tercapainya usaha kesehatan Yayasan untuk meningkatkan kemampuan hidup sehat dan derajat kesehatan santri serta menciptakan lingkungan yang sehat, sehingga memungkinkan dalampertumbuhan dan perkembangan anak yang harmonis dan optimal dalam rangka pembentukan manusia seutuhnya. Sehingga dapat memupuk kebiasaan hidup sehat dan mempertinggi derajat kesehatan santri.

Yayasan Al-Hikmah Mustofa Plered Purwakarta merupakan lembaga pendidikan yang mengutamakan pendidikan akhlak sebagai pendidikan yang paling utama. Sejalan dengan tujuan dari Yayasan Al-Hikmah Mustofa Plered Purwakarta yaitu membentuk generasi yang mandiri dan tanggung jawab. Dengan ini maka interprestasi hasil temuan penelitian akan di paparkan sebagai berikut:

\section{PELAKSANAAN SHALAT BERJAMA'AH DI YAYASAN AL-HIKMAH MUSTOFA}

Berkaitan dengan visi dan misi menjadi yayasan yang berakhlakul karimah sesuai dengan iman dan taqwa kepada Allah SWT di Yayasan Al-Hikmah Mustofa, maka dari itu untuk mewujudkan hal tersebut semua kegiatannya berhubungan erat dalam pembentukan akhlak santri, salah satunya adalah dalam pelaksanaan shalat berjama'ah. Berbicara mengenai shalat berjama'ah memang tidak semua yayasan menerapkan, bila ada yang menerapkan pasti memiliki tujuan yang berbeda, khususunya di yayasan al-hikmah mustofa. Pembinaan akhlak mulia di yayasan sangat terkait dengan pengembangan kultur yayasan. Untuk mencapai hasil yang optimal dalam pembinaan akhlak mulia di yayasan salah satunya adalah dengan mewujudkan visi, misi, dan tujuan yayasan. Yayasan harus mengintegrasikan nilai-nilai ajaran agama dan nilai-nilai akhlak mulia pada segala aspek kehidupan bagi seluruh warga yayasan, terutama para santri.

Tujuan awal dari pelaksanaan shalat berjama'ah awalnya adalah sebagai tindakan untuk memanfaatkan waktu sebaik-baiknya yang sudah ditetapkan dan menjadi tanbih di lingkungan yayasan al-hikmah mustofa untuk melaksanakan shalat berjama'ah. Pembiasaan shalat berjama'ah ini merupakan salah satu program ibadah yang ada di yayasan al-hikmah mustofa plered purwakarta yang mana program ini 
bertujuan untuk membiasakan santri untuk melakukan shalat berjama'ah dikarenakan banyak manfaat dari pelaksanaan ibadah shalat berjama'ah. Maka harapannya akan memunculkan karakter akhlak cinta Tuhan disamping itu juga di dukung dengan adanya pembinaan yang dilakukan oleh pendidik atau guru dan pengurus yang bertugas sebagai fasilitator sebagai pemberi arahan mengenai perilaku sehari-hari dan adab-adab islami yang mana dengan ini juga akan terbentuk akhlak islami yang diharapakan oleh lembaga pendidikan yayasan al-hikmah mustofa plered purwakarta.

Dari hasil wawancara tersebut dapat diketahui bahwa pelaksanaan shalat berjama'ah ini di Yayasan Al-Hikmah Mustofa Plered Purwakarta dilatarbelakangi oleh keadaan para santri yang kurang bisa memanfaatkan waktu dengan sebaikbaiknya. Untuk menanggulangi hal tersebut, pihak lembaga Yayasan Al-Hikmah Mustofa Plered Purwakarta menggunakan waktu sebelum kegiatan pelaksanaan shalat berjama'ah di mulai dengan memberlakukan sebelum adzan 15 menit sudah berada di masjid. Adapun pembahasan mengenai nilai-nilai pendidikan Islam yang terkandung dalam ibadah shalat berjama'ah santri usia remaja akan dipaparkan sebagai berikut:

a. Waktu dan tempat pelaksanaan

Berdasarkan hasil pengamatan pelaksanaan shalat berjama'ah yayasan alhikmah mustofa plered purwakarta dilaksanakan hanyawaktu maghrib, isya dan subuh saja. Sedangkan untuk waktu dzuhur dan ashar santri melaksanakannya di sekolah, terkecuali pada hari libur sekolah semua santri melaksanakan secara bersjama'ah di yayasan tersebut. Pelaksanaan shalat berjama'ah di yayasan al-hikmah mustofa plered purwakarta dilakukan selama dua puluh lima menit, dengan rinciannya yaitu untuk pelaksanaan wudhu dilakukan selama 5 menit, kemudian untuk melaksanakan shalat berjama'ah dilakukan selama 10 menit. Dilanjutkan dengan pembacaan wirid dan doa setelah shalat berjama'ah selama 10 menit kemudian dilanjutkan dengan pengajian sesuai kelas masing-masing. Sedangkan untuk malam kamis selalu diadakan acara muhadlorohan beserta latihan pagar nusa. Pada awal bulan malam selasa yayaysan alhikmah mustofa continue mengadakan manakib Tuan Syaikh Abdul Qodir Al-Zaelany, inilah yang menjadi ciri khas yayasan tersebut.

b. Kegiatan sebelum melaksanakan shalat berjama'ah 
Pelaksanaan shalat berjama'ah dilaksanakan di masjid lingkungan yayasan. Sebelum melaksanakan shalat berjama'ah seluruh santri diwajibkan untuk melaksanakan wudhu terlebih dahulu. Sarana tempat wudhu di Yayasan kurang memadai sehingga dalam pelaksanaannya banyak santri yang harus mengantri lama untuk berwudhu. Namun dalam pelaksanaanya masih ada beberapa santri yang bermain air dan bercanda ketika sedang berwudhu. Setelah semua santri selesai berwudhu, pendidik / pengurus mempersiapkan perlengkapan penunjang seperti sejadah, karpet dan lain sebagainya untuk melaksanakan shalat berjama'ah.

Semua santri mulai bersiap siap untuk melaksanakan shalat berjama'ah, namun sebelum memulai pendidik atau pengurus membimbing seluruh santri untuk membacakan asmaul husna terlebih dahulu. Kegiatan pembacaan asmaul husna sebelum memulai untuk melaksanakan shalat berjama'ah bertujuan untuk meningkatkan rasa kecintaan santri kepada Allah swt. Kegiatan ketika melaksanakan shalat berjama'ah

c. Kegiatan sesudah melaksanakan shalat berjama'ah

Setelah pelaksanaan shalat berjama'ah selesai pendidik atau pengurus membimbing seluruh santri untuk membaca wiridan dan doa. Setelah selesai membaca wirid dan do'a terus pendidik atau pengurus memberikan nasehat, arahan dan bimbingan mengenai keutamaan shalat berjama'ah dan tata cara berperilaku yang baik dan benar yang sesuai dengan norma dan kaidah syariat Islam, setelah itu dilanjutkan dengan mushopaha.

Ketercapaian pelaksanaan shalat berjama'ah di Yayasan Al-Hikmah Mustofa Plered Purwakarta akan tercapai apabila semua santri ikut terlibat dan berperan aktif dalam melaksanakan shalat berjama'ah. Jika santri di Yayasan Al-Hikmah Mustofa Plered Purwakarta tidak mengikuti pelaksanaan Shalat berjama'ah maka santri tersebut mendapat hukuman atau ta'ziran berupa menulis 1000 kalimat Basmalah, pemberiaan hukuman atau ta'ziran ini bertujuan untuk mendisiplinkan santri serta memberi efek jera bagi santri yang melanggar aturan yayasan.

Keberhasilan pelaksanaan shalat berjama'ah di Yayasan Al-Hikmah Mustofa Plered Purwakarta tidak akan berjalan baik tanpa adanya arahan, bimbingan, pengawasan dan kerjasama dari semua pendidik dan pengurus di Yayasan Al-Hikmah Mustofa Plered Purwakarta, guru / pendidik / pengurus memiliki peranan penting dalam 
membimbing santrinya, berdasarkan hasil observasi pelaksanaan shalat berjama'ah di Yayasan Al-Hikmah Mustofa Plered Purwakarta dibimbing oleh pendidik dan pengurus langsung.. Hal ini memberikan kemudahan bagi pendidik dan pengurus untuk terjun langsung ke lapangan karena pendidik dan pengurus lebih memahami karakteristik santrinya.

\section{METODE PELAKSANAAN NILAI-NILAI PENDIDIKAN ISLAM YANG TERKANDUNG DALAM IBADAH SHALAT BERJAMA'AH}

Penerapan pendidikan yang berakhlakul karimah di Yayasan Al-Hikmah Mustofa Plered Purwakarta di integrasikan melalui dua strategi yaitu, pengintegrasikan dalam kegiatan sehari-hari dan pengintegrasikan dalam kegiatan yang diprogramkan, di Yayasan Al-Hikmah Mustofa Plered Purwakarta dari pihak terkait juga mengadakan kegiatan monitoring atau disebut juga dengan memberikan pembentukan akhlak melalui upaya memberikan motivasi maupun tausiyah dan tanya jawab dengan santri dengan tema kepribadian. Setelah itu santri dituntut menerapkannnya di yayasan maupun nanti setelah muqim. Hal ini akan menjalin hubungan kedekatan antara guru dan santri, sehingga santri akan lebih terbuka mengenai masalah pribadinya. Adapun metode yang di pakai dalam membangun akhlakul karimah dalam pelaksanaan shalat berjama'ah di Yayasan Al-Hikmah Mustofa Plered Purwakarta adalah sebagai berikut:

a. Metode Keteladanan

Metode yang sangat efektif untuk membentuk akhlak di yayasan adalah dengan melalui metode keteladanan. Keteladanan di yayasan diperankan oleh ketua harian beserta pendidik dan pengurus yayasan. Keteladanan dalam pendidikan sangat penting dan efektif dalam usaha pembentukan sikap yang berakhlakul karimah. Santri akan lebih mudah memahami dan mengerti dari seseorang yang ditirunya. Keteladanan ini pun menjadi media yang sangat baik bagi optimalnya pembentukan jiwa keberagaman santri. Dalam kasus di Yayasan Al-Hikmah Mustofa plered purwakarta yang juga dituntut untuk memberikan contoh yang baik adalah pendidik dan pengurus yang juga termasuk sebagi pembina akhlak dalam program ibadah shalat berjama'ah.

Keteladanan berbuat jujur dilakukan guru, pendidik dan pengurus dengan cara berbicara sesuai dengan kenyataan yang dilakukan guru, pendidik dan pengurus saat berada di dalam lingkungan yayasan, maupun di luar yayasan. Kemudian guru, pendidik dan pengurus selalu memberi teguran apabila ada santri yang bertengkar. 
Selain itu guru, pendidik dan pengurus juga selalu memberikan motivasi agar santri berbuat jujur saat mengerjakan soal-soal ulangan yang ada di yayasan. Keteladanan tersebut dilakukan guru, pendidik dan pengurus untuk menumbuh kembangakan sikap jujur pada santri. Jujur juga harus dibiasakan dalam kehidupan sehari-hari sehingga sifat itu akan tertanam pada diri kita dengan sendirinya. Menerapkan sikap jujur sebenarnya tidaklah sulit. Agar selalu berada di jalan yang diridhai Allah swt maka harus dimulai dengan niat yang sungguh-sungguh dan dibiasakan dalam kehidupan sehari-hari, sehingga sifat jujur itu akan tertanam pada diri kita sejak kecil. Jika santri berada di lingkungan masyarakat yang kondusif, maka akan berdampak bahwa santri akan terbiasa untuk melakukan perbuatan yang jujur. Dengan memberikan keteladanan bersikap jujur maka dalam diri santri akan tumbuh secara perlahan dan bisa menjadi kebiasaan yang melekat dalam diri santri tersebut, khususnya peserta didik di Yayasan Al-Hikmah Mustofa Plered Purwakarta.

Guru memberikan keteladanan bersikap disiplin dengan cara datang ke masjid lebih awal sebelum waktu adzan di kumandangkan, ketepatan alokasi waktu saat mengajar dan memberikan teladan memakai pakaian sesuai ketentuan dengan rapi. Keteladanan tersebut dimaksudkan untuk menanamkan sikap disiplin pada santri. Disiplin merupakan suatu kondisi yang menunjukan nilai-nilai ketaatan pada aturan. Disiplin akan membuat seseorang tahu dan dapat membedakan hal-hal yang boleh dilakukan dan yang tak sepantasnya dilakukan.

Keteladanan akhlak yang mulia ditanamkan untuk men gembangkan karakter religius pada santri. Untuk mengembangkan keteladanan akhlak mulia, guru membimbing santri untuk kegiatan pembacaan yasin yakni setiap malam Jumat sebelum kegiatan belajar dimulai pada pukul 20.00 hingga pukul 22.00. Sedangkan untuk malam Kamis diadakan kegiatan muhadlrohan, serta satu bulan sekali suka di adakan manakiban. Pemberian keteladanan akhlak mulia ini berdampak bagi santri untuk membentuk karakter santri yang religius.

Keteladanan menunjukan kecerdasan. Kecerdasan sangat diperlukan karena tidak mungkin guru bisa mengajar dengan asal-asalan tanpa adanya bekal ilmu yang memadai. Keteladanan ini untuk mengembangkan karakter kesopanan, tanggungjawab dan kreatif. Keteladanan yang dilakukan guru yaitu mengajarkan santri untuk berperilaku yang sopan dengan memberikan pesan moral saat berbicara tidak melotot 
dan tidak bersuara keras, kemudian mampu menguasai materi yang disampaikan saat mengajar, selain itu guru juga mampu menciptakan pembelajaran yang menyenangkan dengan memadukan diskusi, tanya jawab, atau mengerjakan soal-soal latihan dan dapat juga diselangi dengan menyanyi saat pembelajaran agar peserta didik tidak mearsa bosan. Guru haruslah bersikap bijak dan sekreatif mungkin agar disenangi peserta didiknya. Jiwa yang kreatif terlahir dari sebuah pemikiran guru yang selalu ingin berinovasi sehingga selalu bervariasi dalam memberikan materi kepada peserta didiknya.

Keteladanan menunjukan sikap bekerja keras dan mandiri. Mandiri dan bekerja keras sangat erat kaitannya, karena dengan perilaku santri yang mampu bekerja keras akan membentuk sikap kemandirian yang tidak selalu bergantung pada orang lain. Guru memberikan keteladanan bersikap mandiri dan bekerja keras dengan selalu memberikan motivasi, pesan moral, dan bimbingan apabila santri merasa kesulitan kemudian melibatkan peserta didik agar aktif dalam pembelajaran, selain itu guru memberikan teladan dengan selalu giat belajar dan semangat dalam mengajar.

Terkait dengan pelaksanaan nilai-nilai pendidikan Islam yang terkandung dalam ibadah shalat berjama'ah santri usia remaja di Yayasan Al-Hikmah Mustofa Plered Purwakarta, guru sudah mampu untuk menjadi cermin yang baik bagi santrinya dan mampu menumbuhkan serta menciptakan keteladanan bagi anak didiknya. Guru sudah menerapkan keteladanan semaksimal mungkin untuk memberikan teladan yang baik dalam bentuk karakter santri yang berpegang pada empat kompetensi guru meliputi kompetensi pedagogik, kepribadian, profesional dan sosial. Dalam menerapkan keteladanan ini guru senantiasa berlaku sesuai teladan yang menerapkan keteladanan Nabi saw yang sesuai dengan perintah Allah dan Rasulullah saw dengan memiliki kesamaan antara apa yang diucapkan dengan apa yang dilakukan.

b. Metode pembiasaan

Cara ini adalah nilai-nilai pendidikan Islam melalui semua kegiatan di luar pembelajaran yang biasa disebut kegiatan-kegiatan keagamaan yang berbentuk pembiasaan-pembiasaan nilai-nilai akhlak mulia yang di dalamnya, seperti melalui kegiatan shalat berjama'ah, wiridan,manakiban dan muhadlrohan. Setelah selesai melaksanakan shalat berjama'ah santri selalu melakukan dzikir yang dipimpin oleh pendidik dan pengurus. Dilanjutkan dengan kegiatan pemberian nasehat dan bimbingan 
dari guru mengenai keutamaan shalat berjama'ah serta mengenai tata cara berperilaku yang baik dan benar yang sesuai dengan kaidah Islam.

Dengan demikian dengan adanya metode pembiasan yang positif maka pertumbuhan perkembangan akhlak peserta didik di Yayasan Al-Hikmah Mustofa akan terarah sehingga mereka akan berperilaku yang baik, baik dilingkungan sekolah maupun dilingkungan luar sekolah.

c. Metode pemberian nasehat dan perhatian

Metode pemberian nasehat dan perhatian juga diterapkan dalam pembentukan akhlak santri di Yayasan Al-Hikmah Mustofa dengan cara memberi memotivasi kepada santri untuk memiliki komitmen dengan aturan atau nilai-nilai akhlak mulia yang harus diterapkan. Hal ini, seperti memberikan pertanyaan pembuka "Siapa yang tadi pagi shalat subuh?" Metode ini juga digunakan Guru saat membina para santri untuk melaksanakan shalat berjama'ah.

d. Sanksi

Sanksi diberikan apabila peserta didik melanggar aturan atau tata tertib yang telah dibuat oleh pihak Yayasan. Tujuan dari sanksi ini adalah untuk mendisiplinkan santri serta membuat efek jera bagi santri yang melanggar aturan atau tata tertib yayasan. Berdasarkan hasil observasi penulis menemukan bagi santri yang tidak mengikuti shalat berjama'ah tanpa alasan yang jelas maka akan diberi hukuman berupa menulis 1000 kalimat basmalah. Kemudian jika santri tersebut masih terus melanggar maka pihak yayasan di yayasan al-hikmah mustofa plered purwakarta akan memanggil kedua orang tua nya. Jadi dapat disimpulkan bahwa sanksi yang diberikan bagi santri yang tidak mengikuti pelaksanaan shalat berjama'ah adalah diberi hukuman berupa menulis 1000 kalimat basmalah, serta jika santri tersebut masih terus melanggar maka pihak yayasan di yayasan al-hikmah mustofa plered purwakarta akan memanggil kedua orangtuanya.

\section{NILAI-NILAI PENDIDIKAN ISLAM YANG TERKANDUNG DALAM IBADAH SHALAT BERJAMA'AH SANTRI USIA REMAJA}

Esensi Shalat memiliki dampak spritualitas rohani bagi seseorang yang mengerjakannya, namun dampak spritualitas itu akan dirasakan apabila melaksanakan shalatnya dengan penuh kekhusuan, adapun nilai-nilai pendidikan Islam yang 
terkandung dalam ibadah shalat berjama'ah santri usia remaja di yayasan al-hikmah mustofa sebagai berikut:

\section{a. Kesabaran}

Dalam pelaksanaan shalat berjama'ah yang diikuti oleh seluruh santri di yayasan al-hikmah mustofa plered purwakarta diharapkan sifat sabar dapat diaplikasikan dalam kehidupan sehari-hari, seperti yang telah penulis teliti ketika santri akan melaksanakan shalat berjama'ah para santri bersabar mengantri menunggu giliran untuk berwudhu. Dengan demikian dapat diketahui bahwa sikap sabar tidak hanya bisa diaplikasikan ketika di dalam pelaksanaan shalat berjama'ah saja, tetapi di luar pelaksanakan shalat berjama'ah juga dapat diaplikasikan dengan bersabar ketika guru memberikan ulangan mingguan dadakan dan ketika ada teman yang usil dengan tidak membalasnya.

b. Kedisiplinan

Disiplin merupakan suatu sikap yang harus dimiliki oleh setiap peserta didik sebagai tangga untuk mencapai prestasi belajar yang membanggakan, juga sebagai bukti ketaatan peserta didik terhadap peraturan di yayasan.

c. Konsentrasi

Dalam pelaksanaan shalat, konsentrasi dan kekhusyuan sangat penting dilaksanakan, karena orang yang bisa konsentrasi dan khusyu dalam shalatnya akan mendapatkan ketenangan lahir dan batin. Para santri di yayasan al-hikmah mustofa plered purwakarta diajarkan, dan dibimbing untuk bisa melaksanakan shalat dengan khusyu dan berkonsentrasi ketika sedang shalat. Berdasarkan hasil observasi konsentrasi santri terlihat ketika melaksanakan shalat berjama'ah dengan tidak terburuburu dalam melaksanakan gerakan shalat. selain dari itu konsentrasi santri ketika sedang shalat juga terbawa ketika sedang melaksanakan pembelajaran di dalam pengajian. Dari ungkapan tersebut sudah jelas bahwa shalat dapat melatih konsentrasi siswa dalam belajar. Jadi dapat disimpulkan bahwa shalat berjama'ah dapat melatih konsentrasi santri di yayasan al-hikmah mustofa plered purwakarta dalam belajar dan menyerap ilmu pengetahuan di yayasan.

d. Kebersihan 
Kebersihan sebelum shalat, seseorang diisyaratkan untuk mensucikan dirinya terlebih dahulu, yaitu dengan berwudhu atau bertayamum. Hal ini mengandung pengertian bahwa shalat hanya boleh dikerjakan oleh orang yang suci dari segala bentuk kotoran dan najis. Kebersihan yang dituntut bukanlah secara fisik semata, akan tetapi meliputi aspek non fisik sehingga diharapkan orang yang terbiasa melakukan shalat akan bersih secara lahir dan batin.

Selain dari itu dampak shalat terhadap kebersihan juga terlihat di masjid dan di lingkungan yayasan. Berdasarkan yang penulis amati kebersihan di lingkungan kelas terlihat cukup baik, tidak ada sampah yang berserakan. Lantai masjid terlihat bersih karena setiap hari santri yang kebagian jadwal piket mengepel masjid tersebut. Untuk menjaga agar lantai masjid tetap bersih. Hal ini bertujuan untuk memberikan kenyamanan kepada santri ketika santri berada di dalam masjid. Sedangkankebersihan di lingkungan yayasan terlihat cukup bersih dengan tidak adanya sampah yang berserakan di mana-mana. Adapun cara untuk menanggulangi agar lingkungan yayasan tetap bersih adalah dengan menyediakan tempat sampah yang cukup dan memadai sehingga peserta didik tidak akan membuang sampah sembarangan.

e. Sugesti kebaikan

Bacaan-bacaan di dalam shalat adalah kata-kata yang baik yang banyak mengandung pujian sekaligus do'a kepada Allah swt. Memuji Allah swt artinya mengakui kelemahan kita sebagai manusia, sehingga melatih diri untuk menjadi orang yang rendah hati dan tidak sombong. Berdo'a, selain bermakna nilai kerendahan hati, sekaligus juga menumbuhkan sikap optimis dalam kehidupan. Pengucapan kata-kata bacaan shalat merupakan suatu proses auto sugesti, yang berusaha mewujudkan apa yang telah diucapkannya tersebut dalam kehidupan sehari-hari.

\section{KESIMPULAN}

Yayasan Al-Hikmah Mustofa memiliki tanbih atau peringatan untuk seluruh santri yang ada, salah satu dari tanbih tersebut ialah tentang di wajibkannya seluruh santri melaksanakan shalat berjama'ah. Yayasan Al-Hikmah Mustofa Plered Purwakarta didalam mengajarkan dan melaksanakan nilai-nilai pendidikan Islam yang terkandung dalam ibadah shalat berjama'ah santri usia remaja , tidak hanya dengan suatu perintah saja melainkan dicontohkan langsung serta dilaksanakan bersama-sama dari mulai rasa kesabaran, konsentrasi, kebersihan, sugesti kebaikan, kemandirian, 
Nilai-Nilai Pendidikan Islam Yang Terkandung Dalam Ibadah Shalat Berjama'ah Santri Usia Remaja

tanggung jawab, mematuhi aturan, kedisiplinan, ketertiban serta ketenangan lahir dan bathin. Di Yayasan Al-Hikmah Mustofa Plered Purwakarta, yang ditonjolkan tentang pengaplikasian nilai-nilai pendidikan Islam yang terkandung dalam ibadah shalat berjama'ah santri usia remaja lebih kepada akhlak yang baik.

\section{DAFTAR PUSTAKA}

Abu Ahmadi, Dasar-Dasar Pendidkan Agama Islam. Jakarta: Bumi Aksara, 1991

Abu 'Abdul Mu'ti Muhammad Nawawi Al-Jawwi Al-Bantani, Safinatunnajah Semarang: Toha Putra, 12 Jumadil ula, $1341 \mathrm{H}$

Abdul Qadir Ar-Rohbawi, Shalat Empat Madzhab. Bogor : PT. Pustaka Litera Antar Nusa, 1995

Abujamin Rohman, Shalat Tiang Agama. Jakarta : Media Da’wah, 1992

Basrowi, Pengantar Sosiologi. Bogor: Ghalia Indonesia, 1998

Baharuddin, Moh. Makin, Pendidikan Humanistik ; Konsep, Teori, dan Aplikasi Praktis dalam Dunia Pendidikan. Jogjakarta : Ar-Ruzz Media, 2007

Daryanto, Kamus Lengkap Bahasa Indonesia. Surabaya: Apollo, 1998

Daradjat Zakiyah, dkk. Ilmu Pendidikan Islam. Jakarta : Bumi Aksara, 1991

Daud Rasyid, Islam Dalam Berbagai Dimensi. Jakarta; Gema Insani Press, 1998

Djam'an Satori dan Aan Komaiah, Metodologi Penelitian Kualitatif . Bandung: Alpha Beta, 2009

Hasan Langgulung, Asas-Asas Pendidikan Islam. Jakarta : Pustaka Al-Husna, 1988

H. M. Arifin, Ilmu Pendidikan Islam : Tinjauan Teoritis dan Praktis Berdasarkan Pendekatan Interdisipliner. Jakarta : Bumi Aksara, 2003

Heri Noer Aly, Ilmu Pendidikan Islam. Ciputar: PT Logos Wacana Ilmu, 1999

Fathiyyah Hasan Sulaiman, Alam Pikiran Al-Ghazali Mengenai Pendidikan dan Ilmu. Bandung: Diponegoro, 1986

Hasan Langgulung, Asas-Asas Pendidikan Islam. Jakarta; Pustaka Al-Husna, 1998

Ifrosin, Kisah-Kisah Santri Seri I. Kediri: CV. Sumenang, Mu'jizat Grup, 2005

Koentjaningrat, Metode-metode penelitian masyarakat. Jakarta; Gramedia, 1980

Moh. Nazir, Metode Penelitian. Jakarta; Ghalia Indah, 1988 
Nilai-Nilai Pendidikan Islam Yang Terkandung Dalam Ibadah Shalat Berjama'ah Santri Usia Remaja

M. Ali Hasan, Mukti Ali, Kapita Selekta Pendidkan Agama Islam.Jakarta: Pedoman Ilmu Jaya, 2003

Nasruddin Razak, Dienul Islam. Bandung: PT Al-Maarif, 1995

Risieri Frondizi, Filsafat Nilai . Yogyakarta: Pustaka Pelajar, 2007

Rohman Mulyana, Mengartikulasikan Pendidikan Nilai. Bandung: Alfabeta, 2004

Syamsudin Abu 'Abdillah Muhammad bin Qosim As-Syafi'I, Kitab Fathul Qorib AlMujib. Semarang :23 Rajab $1431 \mathrm{H}$

Sanapiah Faisal, Sosiologi Pendidikan . Surabaya: Usaha Nasional, 1987

Syaikh Zainuddin bin Abdul Aziz Al-Malibari, Terjemah Fathul Mu'in. Surabaya: AlHidayah. Juz I

Syahminan Zaini, Bimbingan Praktis Tentang Shalat. Surabaya : Al-Ikhlas

Sugiyono, Metode Penelitian Kuantitaif, Kualitatif, dan R\&D. Bandung: Alfabeta,cv 2017)

Sutrisno Hadi, Metodologi Research. Jakarta; Cipta karya, 1991

Suharsimi Arikunto, Prosedur penelitian suatu pendekatan praktek. Jakarta; Rineka Cipta, 1998

Ust. Hambali, Aku Anak Shaleh Pandai Shalat dan Berdo 'a. Jawa Tengah : Tawadhu, 2012

Zamakhsyari Dhofier, Tradisi Pesantren Studi Pandangan Hidup Kyai dan Visinya Mengenai Masa Depan Indonesia . Jakarta: LP3ES, 2 
Nilai-Nilai Pendidikan Islam Yang Terkandung Dalam Ibadah Shalat Berjama'ah Santri Usia Remaja 